\title{
Field performance of abnormal maize seedlings
}

\author{
Bojana Vujošević* · Petar Čanak · Milosav Babić · Milan Mirosavljević · \\ Bojan Mitrović · Dušan Stanisavljević · Mladen Tatić
}

Institute of Field and Vegetable Crops, M. Gorkog 30, 21000 Novi Sad, Serbia

\begin{abstract}
Summary: The aim of this study was to investigate field emergence parameters, number of plants that reached reproductive stage and yield of seed lots with different count of abnormal seedlings. In standard germination test these seedlings are discarded from the count of germinated seed, presuming that they will not develop into normal plants. Five lots of hybrid NS 640 with different percentage of abnormal seedlings were tested. Results showed that in favourable environment conditions, large number of abnormal seedlings emerged, reached reproductive stage and participated in yield formation. However, emergence of seed lots with high percentage of abnormal seedlings was longer than for lots with small number of abnormal seedlings. Laboratory germination and germination energy were more correlated with indicators of field emergence rate, while total percentage of germinated seedlings (normal and abnormal) was more correlated with grain yield. However, it can be expected that in adverse environment conditions, abnormal seedlings are less likely to develop into normal plants.

Keywords: emergence, germination, maize, plants, seedlings, seeds
\end{abstract}

\section{Introduction}

Fast and uniform seed emergence and final germination are key components of successful crop production and high yields (Ghassemi-Golezani et al. 2008). Therefore, it is essential to use high quality and vigorous seed, as adequate timing and uniform emergence result in successful competition with weed species, susceptibility to pathogens and insects, proper transition from vegetative to generative stages, and finally maturity (Forcella et al., 2000).

According to several authors (Ghassemi-Golezani et al., 2010; Ghassemi-Golezani et al., 2011; Marcos-Filho, 2015), maximum seed quality is achieved at the end of seed filling period. Different seeds have various life spans and shelf lives, but all eventually start to deteriorate (Walters et al. 2005). Seed deterioration is expressed in lower vigour, increased sensitivity to stresses during germination, delayed emergence, decreased seedling growth, higher number of abnormal seedlings, and loss of ability to germinate (Rajjou \& Debeaujon, 2008; Khajeh-Hosseini et al., 2010; Mohammadi et al., 2011). As a result of numerous factors interacting during plant growth, seed maturation and harvest, different seed quality and longevity among

Corresponding author:

bojana.vujosevic@ifvcns.ns.ac.rs

Acknowledgements:

This study is a part of the project TR 31073 (Improvement of maize and sorghum production under stress) financed by the Ministry of Education, Science, and Technological Development of the Republic of Serbia. species and seed lots can be expected (Egli et al., 2005; Walters et al. 2010; Groot et al., 2012; Nguyen et al., 2012).

The evaluation of seed quality is based upon information provided by the seed testing laboratories. For commercial seeds, the most common data obtained from standard seed tests are germination, analytical purity, and presence of other species seeds, pathogens and moisture content. According to ISTA rules (2009), seedlings with missing, deformed or badly damaged essentials structures, weak, diseased and decayed seedlings are classified as abnormal and discarded from the count of germinated seed, presuming that those seedlings will not develop into normal plants. However, Babić et al. (2015) found that in field, under optimal conditions, large number of abnormal seedlings of different maize landraces accessions can reach the stage of four to five leaves and would afterwards develop into normal plants. Therefore, the aim of this study was to investigate field emergence parameters, number of plants that reached reproductive stage and yield of seed lots with different count of abnormal seedlings.

\section{Material and Method}

Five seed lots of NS 640 hybrid developed at the Institute of Field and Vegetable Crops, Novi Sad were used in this study conducted in 2017. Prior to planting, seeds were tested in Laboratory for Seed Testing of the Institute of Field and Vegetable Crops in Novi Sad, in sterile moistened sand, according to ISTA rules (ISTA, 2009). Three lots with different percentage of abnormal seedlings, but with total germination (normal and 
abnormal seedlings) of $93-94 \%$ were chosen for the study (lots 1, 2 and 3). As control, two seed lots with over 90\% normal seedlings were used. One control lot (lot 4) was chosen to have similar total germination $(94 \%)$ as the tested lots, and the other one (lot 5) with high number of normal (97\%) and just one abnormal seedling in standard laboratory germination test (Table 1).

The soil was ploughed in November, after winter wheat as forecrop, at the depth of $30 \mathrm{~cm}$. After soil analysis, fertilizers were applied as follows: $250 \mathrm{~kg}$ of MAP in the fall and $120 \mathrm{~kg}$ of urea shortly before sowing. Seeds were treated with fungicide Maxim XL 035 FS, with dose recommended by the producer. Planting was conducted on May 11, with $75 \mathrm{~cm}$ between rows and $22 \mathrm{~cm}$ in-row distance (equivalent to 60,606 plants per hectare). The experimental field was not irrigated during vegetation, and total rainfall between planting and harvest was $136 \mathrm{~mm}$ (www.fieldclimate.com).

The experimental design was completely randomized with five replicates. Each replicate was planted in four rows, with 25 seeds per row (plot area $16.5 \mathrm{~m}^{2}$ ). Seedling emergence was counted daily, and final emergence (FE) was recorded when no newly emerged seedlings were observed. Mean emergence time (MET) was calculated using formula (Ellis \& Roberts, 1981):

$$
M E T=\sum D n / \sum n
$$

where $D$ is the number of days counted from the beginning of emergence and $n$ is the number of seeds that had emerged on day $D$.
Time to $50 \%$ emergence $\left(\mathrm{T}_{50}\right)$ was calculated with the formula of Coolbear et al. (1984), modified by Farooq et al. (2005):

$$
T_{50}=t_{i}+\left(\mathrm{N} / 2-n_{i}\right)\left(t_{j}-t_{i}\right) /\left(n_{j}-n_{i}\right)
$$

where $N$ is the final number of emerged seeds, $n_{\mathrm{j}}$ and $n_{\mathrm{i}}$ are the cumulative number of seeds emerged by adjacent counts at times $t_{\mathrm{j}}$ and $t_{\mathrm{i}}$, respectively, when $n_{\mathrm{i}}<$ $N / 2<n_{j}$.

Emergence index (EI) was calculated according to The Association of Official Seed Analysis (1983) formula:

EI $=$ No. of emerged seeds $/$ Day of first count $+\ldots+$ No. of emerged seeds/Day of final count.

Number of plants that reached reproductive stage (NP) was counted 3 months after planting. Harvest was conducted with Wintersteiger Split combine harvester at grain moisture content $25-30 \%$. To prevent border effect, grain yield (GY) was collected from two middle rows (plot area $8.25 \mathrm{~m}^{2}$ ) and expressed at $14 \%$ moisture content.

Data were analysed using analysis of variance. Means were compared using Tukey's test with 95\% confidence interval. Pearson's correlation coefficient was determined at significance probability level of 0.05 .

Table 1. Germination energy (GE), germination (G), abnormal seedlings (A) and total germination (G+A) of five NS 640 seed lots in standard germination laboratory test

\begin{tabular}{lcccc}
\hline Seed lot & GE $(\%)$ & G $(\%)$ & A $(\%)$ & G+A $(\%)$ \\
\hline Lot 1 & 27 & 29 & 64 & 93 \\
Lot 2 & 36 & 37 & 57 & 94 \\
Lot 3 & 52 & 56 & 38 & 94 \\
Lot 4 & 90 & 91 & 3 & 94 \\
Lot 5 & 95 & 97 & 1 & 98 \\
\hline
\end{tabular}

Table 2. Final emergence (FE), mean emergence time (MET), time to 50\% emergence $\left(\mathrm{T}_{50}\right)$, emergence index (EI), number of

\begin{tabular}{|c|c|c|c|c|c|c|}
\hline Seed lot & FE (\%) & MET (days) & $\mathrm{T}_{50}$ (days) & EI & NP & GY (kg) \\
\hline Lot 1 & $77.80 \mathrm{~b}$ & $14.42 \mathrm{a}$ & $7.13 \mathrm{~b}$ & $83.39 \mathrm{~b}$ & $67.60 \mathrm{~b}$ & $5.85 \mathrm{~b}$ \\
\hline Lot 2 & $78.20 \mathrm{~b}$ & $14.54 \mathrm{a}$ & $7.46 \mathrm{a}$ & $81.17 \mathrm{~b}$ & $69.60 \mathrm{ab}$ & $5.90 \mathrm{~b}$ \\
\hline Lot 3 & $78.60 \mathrm{~b}$ & $14.45 \mathrm{a}$ & $7.25 \mathrm{ab}$ & $83.71 \mathrm{~b}$ & $70.00 \mathrm{ab}$ & $5.76 \mathrm{~b}$ \\
\hline Lot 4 & $84.80 \mathrm{ab}$ & $14.10 \mathrm{~b}$ & $6.58 \mathrm{c}$ & $98.57 \mathrm{a}$ & $76.40 \mathrm{ab}$ & $6.20 \mathrm{ab}$ \\
\hline Lot 5 & $90.40 \mathrm{a}$ & $13.96 \mathrm{~b}$ & $6.35 \mathrm{c}$ & $109.18 \mathrm{a}$ & $81.80 \mathrm{a}$ & $6.92 \mathrm{a}$ \\
\hline
\end{tabular}
plants in reproductive stage (NP) and grain yield (GY) of five NS 640 seed lots 


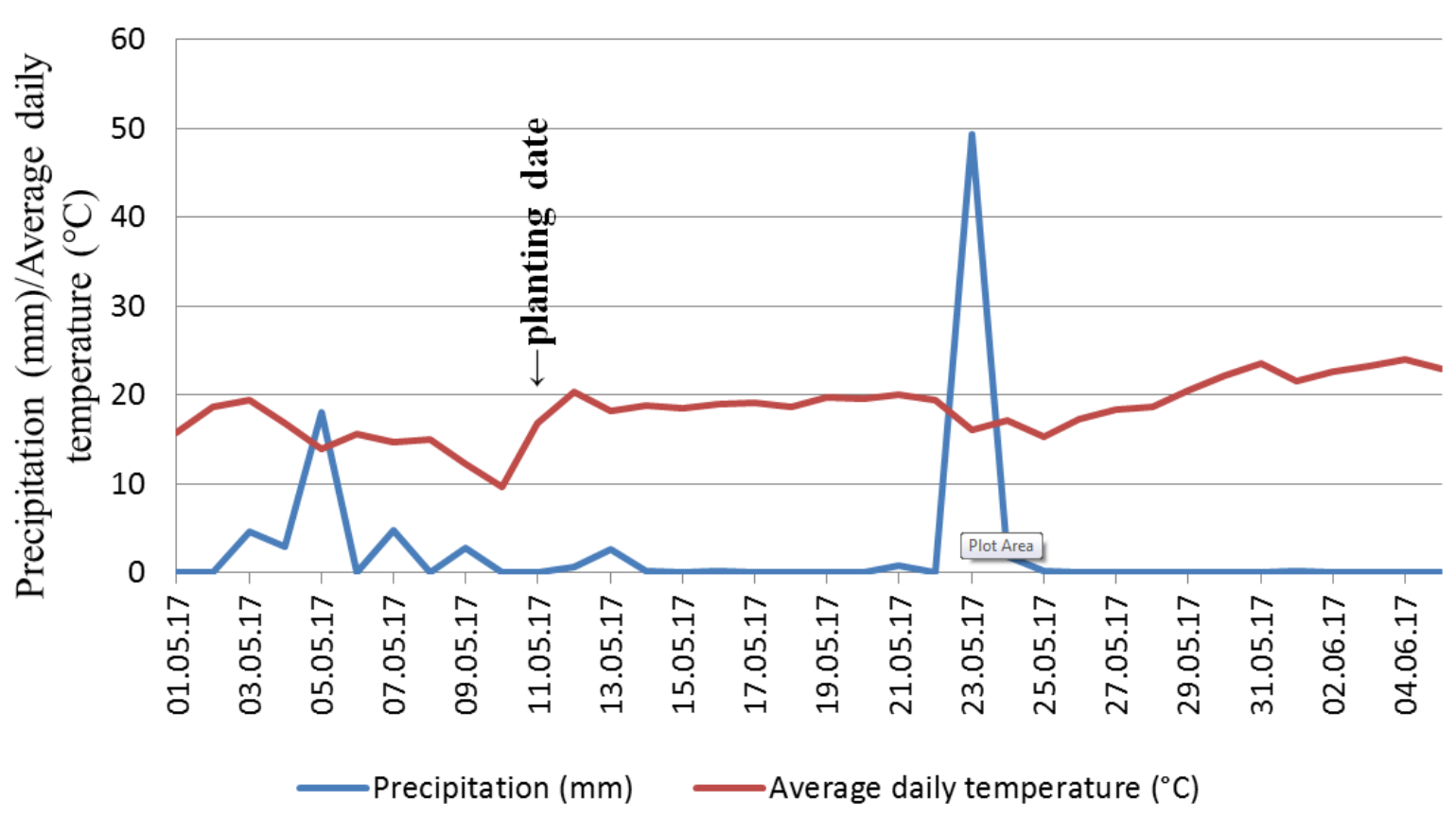

Figure 1. Weather conditions during emergence of NS 640 seed lots

\section{Results and Discussion}

Results show that there were no significant differences in FE of lots 1, 2, 3, and control lot 4 (Table 2). This may be due to favourable environment conditions during emergence, with substantial soil moisture content and average daily temperatures ranging from 15.3 to $23.6{ }^{\circ} \mathrm{C}$ (Figure 1). As a result, large number of abnormal seedlings emerged in field. On the other hand, FE of lots 1,2 and 3 were significantly lower than lot 5 , which can be explained with high laboratory germination of lot 5 (97\% normal and $1 \%$ abnormal seedlings).

Parameters MET and $T_{50}$ of lots 1,2 and 3 were significantly higher than lots 4 and 5, while EI was lower, indicating slower emergence.
Analysing NP, significant differences were detected only between lots 1 and 5. This is in agreement with findings of Babić et al. (2015), who concluded that under favourable environmental conditions, large number of abnormal seedlings would develop into normal plants. This conclusion was partially supported by the results of GY, which in lots 1, 2 and 3 was not significantly different from control lot 4 , but was lower than lot 5. Comparing laboratory germination and field performance, results indicate that in lots 1,2 and 3 at least 22 to 48 abnormal seedlings (out of 100 planted seeds) emerged in field conditions, and 14 to 38 reached reproductive stage (calculated by subtracting laboratory germination from FE and NP, respectively). It has to be noted that these results were obtained in a year when period with favourable conditions for emergence was followed by extreme drought for the rest of the growing period.

Table 3. Correlation coefficients among germination energy (GE), germination (G), total germination (G+A), final emergence (FE), mean emergence time (MET), time to $50 \%$ emergence $\left(\mathrm{T}_{50}\right)$, emergence index $(\mathrm{EI})$, number of plants in reproductive stage (NP) and grain yield (GY)

\begin{tabular}{|c|c|c|c|c|c|c|c|c|}
\hline & GY & NP & EI & $\mathrm{T}_{50}$ & MET & $\mathrm{FE}$ & $\mathrm{G}+\mathrm{A}$ & G \\
\hline GE & 0.81 & $0.95 *$ & $0.93^{*}$ & $-0.90^{*}$ & $-0.93^{*}$ & $0.93^{*}$ & 0.71 & $0.99 *$ \\
\hline G & 0.80 & $0.95^{*}$ & $0.92^{*}$ & $-0.90 *$ & $-0.92^{*}$ & $0.92^{*}$ & 0.72 & \\
\hline$G+A$ & $0.94 *$ & $0.88^{*}$ & 0.84 & -0.71 & -0.75 & $0.88^{*}$ & & \\
\hline $\mathrm{FE}$ & $0.97 *$ & $0.99 *$ & $0.99 *$ & $-0.94^{*}$ & $-0.97^{*}$ & & & \\
\hline MET & $-0.90 *$ & $-0.95^{*}$ & $-0.99 *$ & $0.99 *$ & & & & \\
\hline $\mathrm{T}_{50}$ & -0.88 & $-0.92^{*}$ & $-0.97 *$ & & & & & \\
\hline EI & $0.95 *$ & $0.98^{*}$ & & & & & & \\
\hline NP & $0.95 *$ & & & & & & & \\
\hline
\end{tabular}

*Pearson's correlation coefficient was determined at probability level of 0.05 
Observing results only for lots 1,2 and 3, in most cases no significant differences were found in tested field parameters, which suggests that different percentage of abnormal seedlings in total germination had little or no effect on field performance of these three lots.

Analysis of correlation coefficients showed that germination energy (GE) and germination (G) were positively correlated with FE, EI, NP and GY, and negatively with MET and $\mathrm{T}_{50}$ (Table 3 ). All correlations, except with GY, were significant. These results suggest that $G E$ and $G$ could be decisive indicators of field emergence rate, represented by parameters MET, $\mathrm{T}_{50}$ and EI. As many authors agree, fast germination and seedling emergence are important factors in crop production, especially in stressful environmental conditions (Mirosavljević et al., 2013; Čanak et al. 2014; Marcos-Filho, 2015).

Positive correlation was recorded between total germination $(\mathrm{G}+\mathrm{A})$ and FE, EI, NP and GY, and negative correlation with MET and $\mathrm{T}_{50}$. However, only correlations with FE, NP and GY were significant. These results imply that in favourable environment conditions, certain number of abnormal seedlings can reach reproductive stage and participate in formation of yield. Similar was reported by Babić et al. (2015) when testing different maize landraces accessions.

\section{Conclusions}

Results of this study showed that in favourable environment conditions, large number of abnormal seedlings emerged, reached reproductive stage and participated in yield formation. However, emergence of seed lots with high percentage of abnormal seedlings was prolonged, as compared to lots with high GE and G. Laboratory germination and germination energy were more correlated with indicators of field emergence rate, while total percentage of germinated seedlings (normal and abnormal) was more correlated with grain yield. These conclusions have to be taken with limitation to environment conditions, as it has to be expected that in adverse environment conditions, abnormal seedlings are less likely to develop into normal plants.

\section{References}

Babić, V., Kravić, N., Babić, M., Popović, A., \& Ivanović, D. (2015). Viability testing of maize landraces accessions from MRIZP gene bank. Romanian Agricultural Research, 32, 85-91.

Coolbear, P., Francis, A., \& Grierson, D. (1984). The effect of low temperature pre-sowing treatment under the germination performance and membrane integrity of artificially aged tomato seeds. Journal of Experimental Botany, 35, 1609-1617. doi:10.1093/ jxb/35.11.1609

Čanak, P., Jocković, M., Ćirić, M., Mirosavljević, M., \& Miklič, V. (2014). Effect of seed priming with various concentrations of $\mathrm{KNO}_{3}$ on sunflower seed germination parameters in in vitro drought conditions. Research on Crops, 15(1), 154-158.

Egli, D.B., TeKrony, D.M., Heitholt, J.J., \& Rupe, J. (2005). Air temperature during seed filling and soybean seed germination and vigor. Crop Science, 45, 1329-1335. doi:10.2135/ cropsci2004.0029

Ellis, R.A., \& Roberts, E.H. (1981). The quantification of ageing and survival in orthodox seeds. Seed Science and Technology, 9, 373-409.

Farooq, M., Basra, S.M.A., Hafeez, K., \& Ahmad, N. (2005). Thermal hardening: A new seed vigor enhancement tool in rice. Acta Botanica Sinica, 47, 187-193.

Forcella, F., Benech Arnold, R., Sanchez, R., \& Ghersa, C. (2000). Modeling seedling emergence. Field Crops Research, 67, 123-139.

Ghassemi-Golezani K., Tajbakhsh, Z., \& Raey, Y. (2011). Seed development and quality in maize cultivars. Notulae Botanicae Horti Agrobotanici Cluj-Napoca, 39(1), 178-182.

Ghassemi-Golezani K., Khomari, S., Dalil, B., HosseinzadehMahootchy, A., \& Chadordooz-Jeddi, A. (2010). Effects of seed aging on field performance of winter oilseed rape. Journal of Food, Agriculture and Environment, 8(1), 175-178.

Ghassemi-Golezani K., Asghar Aliloo, A., Valizadeh, M., \& Moghaddam, M. (2008). Effects of different priming techniques on seed invigoration and seedling establishment of lentil (Lens culinaris Medik). Journal of Food, Agriculture and Environment, 6(2), 222-226.

Groot, S.P.C., Surki, A.A., de Vos, R.C.H., \& Kodde, J. (2012). Seed storage at elevated partial pressure of oxygen, a fast method for analysing seed ageing under dry conditions. Annals of Botany 110, 1149-1159. doi: 10.1093/aob/mcs198

International seed testing association (ISTA) (2009). International rules for seed testing. Zurich: ISTA.

Khajeh-Hosseini, M., Nasehzadeh, M., \& Matthews, S. (2010). Rate of physiological germination relates to the percentage of normal seedlings in standard germination tests of naturally aged seed lots of oilseed rape. Seed Science and Technology, 38(3), 602-611.

Nguyen, T., Keizer, P., van Eeuwijk, F., Smeekens, S., \& Bentsink, L. (2012). Natural variation for seed longevity and seed dormancy are negatively correlated in Arabidopsis. Plant Physiology, 160, 20832092.

Marcos-Filho, J. (2015). Seed vigor testing: an overview of the past, present and future perspective. Sciencia Agricola, 72(4), 363-374.

Mirosavljević, M., Čanak, P., Ćirić, M., Nastasić, A., Đukić, D. \& Rajković, M. (2013). Maize germination parameters and early seedlings growth under different levels of salt stress. Ratarstvo $i$ Povrtarstvo, 50, 49-53.

Mohammadi, H., Soltani, A., Sadeghipour, H.R., \& Zeinali, E. (2011). Effects of seed aging on subsequent seed reserve utilization and seedling growth in soybean. International Journal of Plant Production, 5(1), 65-70.

Rajjou, L. \& Debeaujon, I. (2008). Seed longevity: Survival and maintenance of high germination ability of dry seeds. Comptes Rendus Biologies, 331, 796-805. doi:10.1016/j.crvi.2008.07.021

The Association of Official Seed Analysis. (1983). Seed Vigor Testing Handbook. Contribution No. 32 to the Handbook on Seed Testing. Association of Official Seed Analysis, Springfield, IL.

Walters, C., Wheeler, L.M., \& Grotenhuis, J.M. (2005). Longevity of seeds stored in a genebank: Species characteristics. Seed Science Research, 15(01), 1-20. doi:10.1079/SSR2004195

Walters, C., Ballesteros, D., \& Vertucci, V. (2010). Structural mechanics of seed deterioration: Standing the test of time. Plant Science, 179, 565-573. doi:10.1016/j.plantsci.2010.06.016 


\section{Ponašanje atipičnih klijanaca kukuruza u poljskoj proizvodnji}

\section{Bojana Vujošević · Petar Čanak · Milosav Babić · Milan Mirosavljević · Bojan Mitrović · Dušan Stanisavljević · Mladen Tatić}

Sažetak: Cilj ovog ispitivanja bio je da se kod partija semena sa različitim udelom atipičnih ponika ispitaju parametri brzine klijanja u polju, broj biljaka u reproduktivnoj fazi i prinos. Ovakvi ponici se u standardnom testu klijavosti ne ubrajaju u klijava zrna, jer se pretpostavlja da neće dati normalnu biljku. Testirano je pet partija hibrida NS 640 sa različitim udelom atipičnih ponika. Rezultati su pokazali da je u povoljnim uslovima veliki broj atipičnih klijanaca nikao, dostigao reproduktivnu fazu i učestvovao u formiranju prinosa. Sa druge strane, nicanje partija sa velikim brojem atipičnih klijanaca je bilo usporeno. Laboratorijska klijavost i energija klijanja su bile u većoj korelaciji sa parametrima brzine nicanja, dok je ukupna klijavost (normalni i atipični klijanci) bila u većoj korelaciji sa prinosom. Ipak, u nepovoljnim uslovima spoljašnje sredine, atipični klijanci imaju manje šanse da se razviju u normalnu biljku. Ključne reči: biljke, kukuruz, klijanci, klijanje, nicanje, seme 